УдК 633.15:661.631

Токмакова Л. М., кандидат сільськогосподарських наук, Трепач А. О., кандидат сільськогосподарських наук, Шевченко Л. А., молодший науковий співробітник

Інститут сільськогосподарської мікробіології та агропромислового виробництва НААН України

\title{
ЕФЕКТИВНІСТЬ ФОСФОРНОГО ЖИВЛЕННЯ РОСЛИН КУКУРУДЗИ ЗА ДІЇ ПОЛІМІКСОАКТЕРИНУ
}

\section{Рецензент - доктор біологічних наук О. В. Надкернична}

Мета статmі - дослідити вплив різних способів застосування мікробного препарату Поліміксобактерину на фосфорне живлення рослин кукурудзи та обтрунтувати ефективність дії нового агроприйому.

Методика досліджень. У процесі дослідження використано польовий метод, біохімічні (визначення вмісту фосфору у зерні та листо-стебловій масі рослин), агрохімічні (визначення виносу фосфору із зерном та побічною продукиією) та статистичні методи.

Результати дослідження. За результатами проведених досліджень встановлено, щяо у середньому за три роки було виявлено тенденцію щодо збільшення вмісту фосфору в зерні кукурудзи дослідних варіантів із застосуванням мікробного препарату до 0,50-0,55\% порівняно з контрольним варіантом, де ией показник склав 0,47\%. Проведення поверхневої обробки вегетуючих рослин у фазі 7-9 листків на фоні бактеризації збільшило загальний винос фосфору з урожаєм зерна на 53,2 \%, з побічною продукиією на $36,3 \%$.

Елементи наукової новизни. Виявлено особливості впливу нового способу застосування Поліміксобактерину, який включає бактеризачію насіння та поверхневу обробку вегетуючих рослин, на інтенсивність фосфорного живлення кукурудзи і винос иього елементу з урожаєм культури.

Практична значущість. На основі експериментальних досліджень встановлено, що при вирощуванні кукурудзи дочільно використовувати агроприйом, щео включає бактеризацію насіння і поверхневу обробку рослин по вегетації Поліміксобактерином, який впливає на підсилення засвоєння фосфору рослинами та сприяє збільшенню його вмісту у листо-стебловій масі і зерні кукурудзи, $i$, як наслідок, підвищується винос иьього елементу з урожаєм культури, що свідчить про підвищення ефективності фосфорного живлення рослин кукурудзи.

Ключові слова: Zea mays L., мікробний препарат Поліміксобактерин, фосфор, бактеризачія насіння, поверхнева обробка рослин по вегетаиії.

Токмакова Любов Миколаївна - старший науковий співробітник, кандидат сільськогосподарських наук, завідувач лабораторії екології грунтових мікроорганізмів, Інститут сільськогосподарської мікробіології та агропромислового виробництва, Національна академія аграрних наук України, вул. Шевченка, 97, м. Чернігів, 14027, Україна, e-mail: tokmakova_ln@ukr.net, ORCID ID: 0000-00015501-2058.

Трепач Алла Олексіївна - кандидат сільськогосподарських наук, старший науковий співробітник лабораторії екології грунтових мікроорганізмів, Інститут сільськогосподарської мікробіології та агропромислового виробництва Національної академії аграрних наук України, вул. Шевченка, 97, м. Чернігів, 14027, Україна, e-mail: alla.trepach@ukr.net, ORCID 0000-0003-1059-9021.

Шевченко Любов Анатоліївна - молодший науковий співробітник лабораторії екології грунтових мікроорганізмів, Інститут сільськогосподарської мікробіології та агропромислового виробництва Національної академії аграрних наук України, вул. Шевченка, 97, м. Чернігів, 14027, Україна, е-таil: shevchenkolyubov@ukr.net, ORCID 0000-0002-2637-1999.

Постановка проблеми. Фосфор - важливий біогенний елемент живлення рослин, і водночас, його доступність $\epsilon$ лімітуючим фактором їх росту і розвитку $[6,17]$. Основні проблеми оптимального забезпечення сільськогосподарських культур фосфором пов'язані з низкою причин, одна 3 яких це низький показник (близько $5 \%$ ) доступності фосфорних сполук грунту для рослин і швидке зв'язування його у важкодоступні для рослин органічні (фітин, фітат тощо) та мінеральні форми (фосфати кальцію, заліза, алюмінію, що входять до складу природних мінералів, таких як апатит, фторапатит, фосфорит, вівіаніт тощо) [13]. Внесення мінеральних фосфорних добрив вирішує 


\section{СІЛЬСЬКЕ ГОСПОДАРСТВО. РОСЛИННИЦТВО}

цю проблему лише частково, оскільки коефіцієнт використання рослинами фосфору з добрив низький (10-25 \%), що призводить до нагромадження у грунті його залишків, а їх виробництво - енергоємний і дороговартісний процес, до того ж у фосфорних добривах міститься найбільша концентрація важких металів та інших токсикантів [2, 12]. Зважаючи на це, увага науковців зосереджена на залученні до вирішення цієї проблеми використання мікробних препаратів, створених на основі мікроорганізмів, які забезпечують мобілізацію фосфору 3 важкодоступних сполук грунту у рухомі легкодоступні форми (ортофосфорна кислота та ii солі, оскільки фосфор засвоюється рослинами у вигляді аніонів фосфорної кислоти: $\mathrm{H}_{2} \mathrm{PO}^{4-}, \mathrm{HPO}_{4}{ }^{2-}$ або $\left.\mathrm{PO}_{4}{ }^{3-}\right)[8,14,18]$.

В Інституті сільськогосподарської мікробіології та агропромислового виробництва було створено мікробний препарат Поліміксобактерин [7], біоагентом якого є фосфатмобілізувальні бактерії Paenibacillus polymyxa КВ, які здатні продукувати фермент фосфатазу, що забезпечує деструкцію органофосфатів, та синтезувати органічні кислоти, які сприяють розчиненню мінеральних фосфатів грунту та добрив. Тому вивчення дії Поліміксобактерину на фосфорне живлення рослин кукурудзи є досить актуальним.

Аналіз останніх досліджень та публікацій, у яких започатковано розв'язання проблеми. Провідну роль у трансформації фосфоровмісних сполук грунту відіграють мікроорганізми. Вони покращують фосфорне живлення рослин завдяки синтезу фосфатаз і органічних кислот, які перетворюють нерозчинні органічні i неорганічні сполуки фосфору в доступні для рослин форми. У різних типах грунтів мікроорганізми, які мобілізують фосфати кальцію, складають від 5,0\% до 95,0 \% від загальної чисельності мікробіоти $[4,15]$. Крім того, фосфатмобілізувальні бактерії часто проявляють фітостимулювальні властивості і антагонізм до фітопатогенів $[3,16]$.

Тривалий час вивченням впливу мікроорганізмів на доступність рослинам фосфору з добрив i фосфоровмісних сполук грунту займається ряд дослідників [5, 8, 9, 14]. Авторами показано, що мобілізація важкорозчинних сполук фосфору грунтовими мікроорганізмами є однією 3 найважливіших ланок його кругообігу, яку забезпечують гетеротрофні і автотрофні мікроорганізмів, на основі яких створені бактеріальні препарати. Суттєвою особливістю фосфорного живлення інокульованих рослин $є$ можливість залучення елементу 3 нижніх горизонтів грунтового профілю, куди переважно переміщуються сполуки фосфору. Розвинена коренева система, іні- ційованих бактеризацією рослин, здатна поглинати фосфати у більшій кількості, тобто відбувається повернення фосфатів у верхні горизонти грунтового профілю.

Серед низки сільськогосподарських культур, що вирощуються у нашій країні особливу увагу необхідно звернути на кукурудзу, фізіологічною особливістю якої є пролонгований період поглинання сполук фосфору з грунту. Хоча рослинами кукурудзи його поглинається менше, ніж азоту, та все ж цей елемент $є$ необхідним для формування кореневої системи і утворення генеративних органів. Важливу роль у засвоєнні фосфору 3 грунту відіграє потужна коренева система рослин кукурудзи, що дуже швидко і активно вбирає поживні речовини [10].

Мета досліджень - вивчення ефективності фосфорного живлення рослин кукурудзи за різних способів застосування Поліміксобактерину.

Завдання досліджень: вивчити вплив різних способів застосування мікробного препарату Поліміксобактерину на вміст фосфору в зерні і вегетативній масі рослин кукурудзи та визначити ефективність фосфорного живлення культури.

Матеріали і методи досліджень. Дослідження проведені протягом 2016-2018 рр. в умовах польових дослідів на чорноземі вилуженому дослідного поля Інституту сільськогосподарської мікробіології та агропромислового виробництва НААН України. Грунт містить 2,12 \% гумусу, 95,2 мг/кг азоту легкогідролізованого, 226 мг/кг фосфору, 108 мг/кг обмінного калію, $\mathrm{pH}_{\text {сол. }}=5,30$.

Схема польового досліду включала такі варіанти: 1) Контроль - без бактеризації та поверхневої обробки (ПО); 2) Поліміксобактерин (бактеризація); 3 ) Бактеризація + поверхнева обробка вегетуючих рослин у фазі 3-5 листків; 4) Бактеризація + поверхнева обробка вегетуючих рослин Поліміксобактерином у фазі 7-9 листків.

Площа дослідної ділянки - 75,6 м², повторність досліду триразова.

Бактеризацію насіння кукурудзи проводили Поліміксобактерином згідно з СОУ 01.11-37783. Поверхневу обробку вегетуючих рослин проводили механізовано. Робоча суміш містила: 200 л води та 0,5 л Поліміксобактерину з розрахунку на 1 га посівів. Вміст фосфору у рослинах та зерні кукурудзи визначали за методом Деніже в модифікації Буватьє [1]. Визначення виносу фосфору з урожаєм зерна та листо-стеблової маси кукурудзи проведені за розрахунковим методом Чирікова [11]. Статистичні розрахунки проводили за використання програм Statistica 6.0, а також Microsoft Office Excel 2007. 
Результати досліджень. Вміст хімічних елементів у рослинах $є$ відображенням умов забезпечення їх поживними речовинами протягом онтогенезу. Про закономірності поглинання поживних елементів свідчать показники хімічного складу рослин (вміст макро- та мікроелементів), які суттєво варіюють залежно від фази розвитку i рівня живлення культури та погоднокліматичних умов.

В умовах польового досліду виявлено, що застосування Поліміксобактерину при вирощуванні кукурудзи сприяє підвищенню вмісту фосфору у листо-стебловій масі інокульованих рослин відносно контролю (табл. 1).

У фазу виходу у трубку максимальний вміст цього елементу накопичувався у вегетативній масі рослин варіанту бактеризація + поверхнева обробка вегетуючих рослин у фазі 7-9 листків $0,52 \%$, у контролі такий показник не перевищував $0,46 \%$. У фазі цвітіння достовірну різницю виявлено між контрольним показником $(0,42 \%)$ та варіантом у якому поєднували бактеризацію насіння з поверхневою обробкою по вегетації у фазі 7-9 листків. У фазу молочно-воскової стиглості зерна, інтенсивність накопичення органічної речовини випереджає надходження елементів живлення з грунту, що і призводить до відносного зниження вмісту фосфору у вегетативній масі - від 0,35\% у контролі до 0,36-0,37 \% у варіантах із застосуванням мікробного препарату. Результати проведеного нами аналізу вмісту фосфору в зерні кукурудзи показали, що високий вміст $\mathrm{P}_{2} \mathrm{O}_{5}$ характерний для варіанту сумісної дії бактеризації насіння та поверхневої обробки ве- гетуючих рослин Поліміксобактерином у фазі 7-9 листків - 0,55 \% (у контролі 0,47 \%).

Розрізняють загальний біологічний і господарський винос поживних речовин із грунту сільськогосподарськими культурами. Біологічний винос представлений загальною кількістю поживних речовин, яку використовують рослини на побудову свого організму, а господарський винос це - та частина, яка міститься в урожаї основної і побічної продукції і виноситься 3 поля.

За результатами досліджень показано, що за дії Поліміксобактерину бактеризація + поверхнева обробка вегетуючих рослин у фазі 7-9 листків винос фосфору зерном підвищувався до 62,2 кг/га, а соломою до 36,4 кг/га при контрольних показниках 40,6 кг/га та 27,6 кг/га відповідно (рис. 1).

Загалом, винос фосфору зерном та листостебловою масою кукурудзи за дії різних способів застосування Поліміксобактерину збільшувався у всіх варіантах порівняно 3 контролем i, особливо, за використання поєднання бактеризації насіння та поверхневої обробки рослин у фазі 7-9 листків.

Дані таблиці 2 свідчать, що загальний винос фосфору 3 урожаєм культури, за результатами трирічних досліджень, становив від 68,6 кг/га у контрольному варіанті до 99,8 кг/га за бактеризації насіння + поверхнева обробка по вегетації у фазі 7-9 листків, що сприяло підвищенню ефективності фосфорного живлення рослин на 45,5 \% (табл. 2).

\section{1. Вміст фосфору (\%) у вегетативній масі та зерні кукурудзи за впливу Поліміксобактерину (у середньому за 2016-2018 рр.)}

\begin{tabular}{|c|c|c|c|c|}
\hline \multirow[b]{3}{*}{ Варіанти досліду } & \multirow{2}{*}{\multicolumn{3}{|c|}{$\begin{array}{c}\text { Листо-стеблова маса } \\
\text { фази розвитку рослин }\end{array}$}} & \multirow[b]{3}{*}{ Зерно } \\
\hline & & & & \\
\hline & $\begin{array}{l}\text { виходу у } \\
\text { трубку }\end{array}$ & цвітіння & $\begin{array}{c}\text { молочно- } \\
\text { воскової } \\
\text { стиглості }\end{array}$ & \\
\hline $\begin{array}{l}\text { Контроль - без бактеризації та поверх- } \\
\text { невої обробки (ПО) }\end{array}$ & $0,46 \pm 0,01$ & $0,42 \pm 0,01$ & $0,35 \pm 0,01$ & $0,47 \pm 0,01$ \\
\hline $\begin{array}{l}\text { Поліміксобактерин } \\
\text { (бактеризація насіння) }\end{array}$ & $0,49 \pm 0,01$ & $0,44 \pm 0,01$ & $0,36 \pm 0,01$ & $0,50 \pm 0,01$ \\
\hline $\begin{array}{l}\text { Бактеризація + ПО вегетуючих рослин } \\
\text { у фазі 3-5 листочків }\end{array}$ & $0,49 \pm 0,01$ & $0,43 \pm 0,01$ & $0,36 \pm 0,01$ & $0,52 \pm 0,01$ \\
\hline $\begin{array}{l}\text { Бактеризація + ПО вегетуючих рослин } \\
\text { у фазі 7-9 листочків }\end{array}$ & $0,52 \pm 0,01$ & $0,45 \pm 0,01$ & $0,37 \pm 0,01$ & $0,55 \pm 0,01$ \\
\hline
\end{tabular}

Джерело: власні дослідження. 


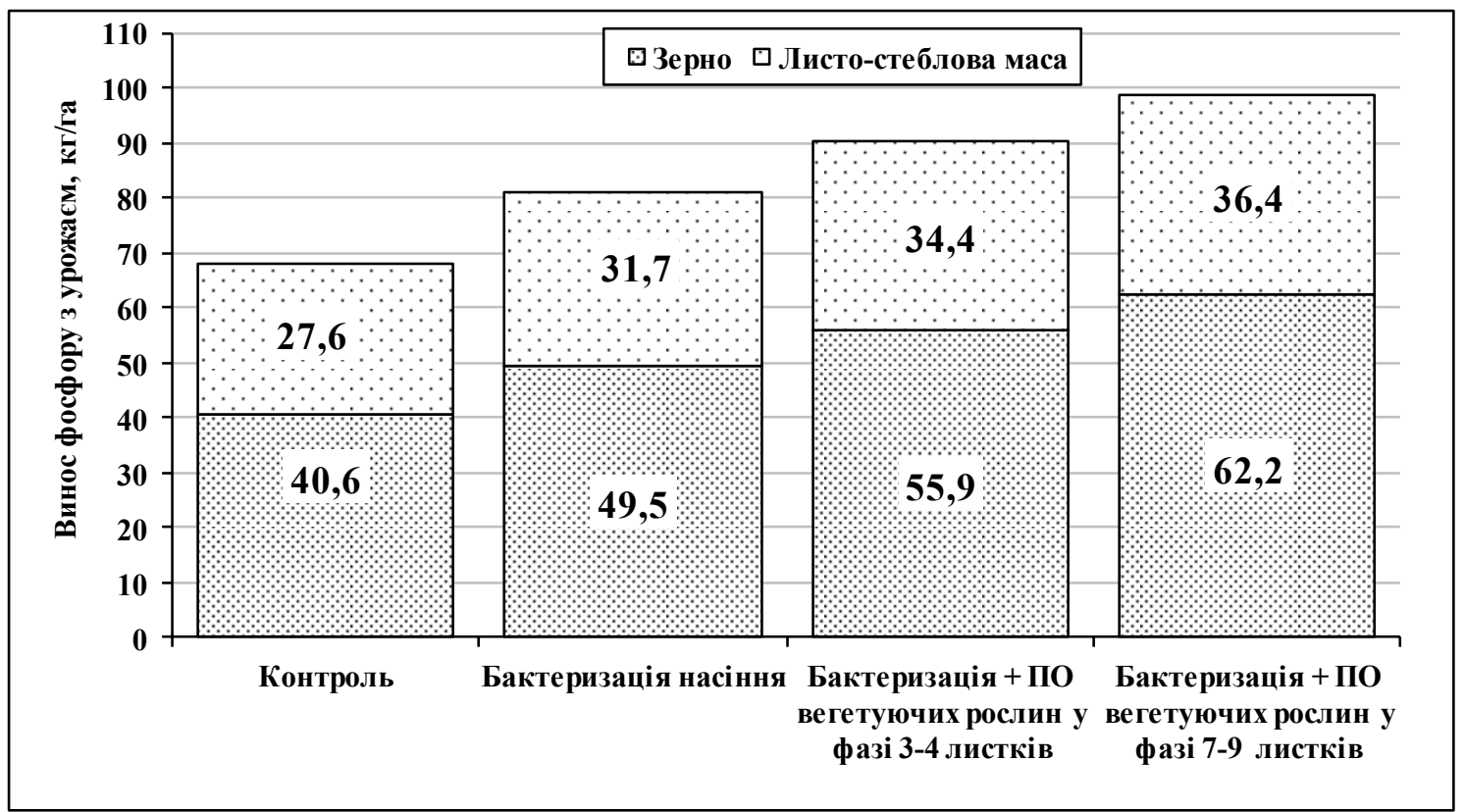

\section{Рис. 1. Вплив Поліміксобактерину на винос фосфору з урожаєм кукурудзи} (у середньому за 2016-2018 рр.)

Джерело: власні дослідження.

\section{2. Ефективність фосфорного живлення рослин кукурудзи за дії Поліміксобактерину (у середньому за 2016-2018 рр.)}

\begin{tabular}{|l|c|c|c|}
\hline \multirow{2}{*}{ Варіанти досліду } & \multirow{2}{*}{$\begin{array}{c}\text { Загальний винос фос- } \\
\text { фору з урожаєм, кг/га }\end{array}$} & $\begin{array}{c}\text { Ефективність фосфорного жи- } \\
\text { влення }\end{array}$ \\
\cline { 3 - 4 } & 68,6 & - & кг/га \\
\hline $\begin{array}{l}\text { Контроль - без бактеризації та поверх- } \\
\text { невої обробки }\end{array}$ & 81,7 & 13,1 & 19,1 \\
\hline Поліміксобактерин (бактеризація) & 91,0 & 22,4 & 32,6 \\
\hline $\begin{array}{l}\text { Бактеризація + поверхнева обробка веге- } \\
\text { туючих рослин у фазі 3-5 листків }\end{array}$ & 99,8 & 31,2 & 45,5 \\
\hline $\begin{array}{l}\text { Бактеризація + поверхнева обробка веге- } \\
\text { туючих рослин у фазі 7-9 листків }\end{array}$ & & & \\
\hline
\end{tabular}

Примітка. ${ }^{*}$ - різниця між показниками загального виносу фосфору з урожаєм досліджуваного і контрольного варіантів.

Джерело: власні дослідження.

Поверхнева обробка вегетуючих рослин кукурудзи Поліміксобактерином є джерелом додаткового надходження біологічно активних речовин, які забезпечують процес активізації ростових процесів у рослинному організмі. Тобто, цей спосіб застосування препарату має опосередкований вплив на процес фосфорного живлення рослин, але у поєднанні з бактеризацією насіння дія препарату є більш ефективною.

Отже, аналізуючи результати трирічних досліджень, варто відзначити, що серед досліджуваних способів застосування мікробного препарату у варіанті, який включає бактеризацію на- сіння і поверхневу обробку по вегетації встановлено збільшення вмісту фосфору у листостебловій масі рослин до $0,52 \%$, та у зерні кукурудзи до $0,55 \%$. Загальний винос фосфору 3 урожаєм культури у цьому варіанті підвищувався на 31,2 кг/га.

Висновок. При вирощуванні кукурудзи доцільно використовувати агроприйом, що включає бактеризацію насіння і поверхневу обробку рослин по вегетації у фазі 7-9 листків Поліміксобактерином - стимулятором росту рослин, біоагентом якого є фосфатмобілізувальні бактерії Paenibacillus polymyxa $\mathrm{KB}$, який впливає на підси- 
лення засвоєння фосфору рослинами та сприяє збільшенню його вмісту у листо-стебловій масі і зерні кукурудзи та, як наслідок, підвищується

\section{БІБЛІОГРАФІЯ}

1. Експериментальна грунтова мікробіологія: монографія / В. В. Волкогон, О. В. Надкернична, Л. М. Токмакова та ін. ; за наук. ред. В. В. Волкогона. Київ : Аграр. наука, 2010. 464 с.

2. Заречений В. Г., Вакал С. В. Кадмій у фосфоровмісних мінеральних добривах. Хімічна промисловість Украӥни. 2003. № 6. С. 18-20.

3. Михайлова Н. А., Гринько О. М. Бактерии рода Bacillus - продуценты биологически активных веществ антимикробного действия. Журнал микробиологии, эпидемиологии и иммунобиолоzuи. 2010. № 3. С. 85-89.

4. Михновская А. Д. Микробиологическая характеристика черноземов Украины и ее применение под влиянием обработки и удобрений. Бюл. ВНИИСХМ. 1986. № 44. С. 12-24.

5. Мікробні препарати в сучасних аграрних технологіях : науково-практичні рекомендації ; за ред. В. В. Волкогона. Київ, 2015. 248 с.

6. Носко Б. С. Сучасні проблеми фосфору в землеробстві і шляхи їх розв'язання. Вісник аграрної науки. 2017. № 6. С. 5-12.

7. Спосіб виготовлення мікробного препарату Поліміксобактерину - стимулятора росту рослин : пат. 99009 Україна : МПК C12N 1/20 (2006.01), C05F 11/08 (2006.01). № u 201413665 ; заявл. 19.02.2014; опубл. 12.05.2015, Бюл. № 9.

8. Пуронен С. В., Жусупова А. М., Тен О. А. Выделение активных культур фосфатмобилизирующих микроорганизмов из ризосферы. Биотехнология. Теория и практика. 2012. № 3. C. $77-82$.

9. Рой А. А. Булавенко Л. А., Курдиш И. К. Новые штаммы почвенных бацилл, минерализующие органические соединения фосфора. Мікробіологічний журнал. 2001. № 4, т. 63. C. 9-14.

10. Физиология сельскохозяйственных рас-

\section{REFERENCES}

1. Volkohon, V. V., Nadkernychna, O. V., Tokmakova, L. M., Melnychuk, T. M., Chaikovska, L. O., Nadkernychnyi, S. P., Sherstoboiev, M. K., et al. (2010). Eksperymentalna gruntova mikrobiolohiia: monohrafiia [Experimental soil microbiology: monograph]. Kyiv: Ahrar. Nauka [In Ukrainian].

2. Zarechenyi, V. H., \& Vakal, S. V. (2003). Kadmii $\mathrm{u}$ fosforovmisnykh mineralnykh dobryvakh винос цього елементу 3 урожаєм культури, що свідчить про підвищення ефективності фосфорного живлення рослин кукурудзи.

тений : т. V (Физиология кукурузы и риса); отв. ред. тома Б. А. Рубин. Изд-во Московского унта, 1969. 416 с.

11. Чириков Ф. В. Агрохимия калия и фосфора. Москва : Гос. изд. с.-х. литературы, 1956. 462 c.

12. Проблема важких металів при виробництві і використанні фосфоровмісних мінеральних добрив (на прикладі Кадмію, Свинцю, Арсену) / Т. О. Яструб, В. В. Кірсенко, С. В Вакал та ін. Український журнал з проблем медицини праці. 2013. № 3 (36). C. 42-49.

13. Abel S. Ticconi C. A., Delatorre C. A. Phosphate sensing in higher plants. Physiol. Plant. 2002. Vol. 115. P. 1-8.

14. Bala Rathinasabapathi, Xue Liu, Yue Cao, Lena Q. Ma. Phosphate-solubilizing Pseudomonads for improving crop plant nutrition and agricultural productivity. Crop Improvement Through Microbial Biotechnology. 2018. P. 363-372.

15. Braunova O., Bernat $Y$. Utilization of phosphorus from $\mathrm{Ca}_{3}\left(\mathrm{PO}_{4}\right)_{2}$ by soil micromycetes. Acta fac. rerum natur. Univ. comen. Microbiol. 1980 (1981). № 8-9. P. 129-142.

16. Kloepper J. W., Ryn C. M., Zhang S. A. Systemic resistance and promotion of plant growth of Bacillus sp. Phytopathology. 2004. Vol. 94. P. 1259-1266.

17. Regulation of phosphorus uptake and utilization: transitioning from current knowledge to practical strategies / Md. Mahmudul Hasan, Md. Mainul Hasan, Jaime A. et al. Cellular and Molecular Biology Letters. 2016. Vol. 21. P. 1-9.

18. Park J., Bolan N., Mallavarapu M., Naidu R. Enhancing the solubility of insoluble phosphorus compounds by phosphate solubilizing bacteria. 19-th World Congres of Soil Science, Brisbane, Australia. 2010. P. 65-68.

[Cadmium in phosphorus-containing mineral fertilizers]. Khimichna promyslovist Ukrainy, 6, pp. 1820 [In Ukrainian].

3. Mihajlova, N. A., \& Grin'ko, O. M. (2010). Bakterii roda Bacillus - producenty biologicheski aktivnyh veshhestv antimikrobnogo dejstvija [Bacteria of the genus Bacillus - producers of biologically active substances with antimicrobial action]. Zhurnal mikrobiologii, jepidemiologii i immunobi- 
ologii, 3, pp. 85-89 [In Russian].

4. Mihnovskaja, A. D. (1986). Mikrobiologicheskaja harakteristika chernozemov Ukrainy i ee primenenie pod vlijaniem obrabotki i udobrenij [Microbiological characteristics of Ukraine's chernozem and its application under the influence of processing and fertilizers]. Bjul. VNIISHM, 44, pp. 12-24 [In Russian].

5. Volkohon, V. V. (2015). Mikrobni preparaty $v$ suchasnykh ahrarnykh tekhnolohiiakh : naukovo-praktychni rekomendatsii [Microbial drugs in modern agrarian technologies : scientific and practical recommendations]. Kyiv [In Ukrainian].

6. Nosko, B. S. (2017). Suchasni problemy fosforu v zemlerobstvi i shliakhy yikh rozv'iazannia [Modern problems of phosphorus in agriculture and ways of their solution]. Visnyk ahrarnoi nauky, 6, pp. 5-12 [In Ukrainian].

7. Sposib vyhotovlennia mikrobnoho preparatu Polimiksobakterynu - stymuliatora rostu roslyn : pat. 99009 Ukraina [Method of manufacturing microbial preparation Polymiksobakterin - a growth stimulator of plants: pat. 99009 Ukraine]. (2015). MPK S12N 1/20 (2006.01), S05F 11/08 (2006.01). № u 2014 13665. Bul. № 9 [In Ukrainian].

8. Puronen, S. V., Zhusupova, A. M., \& Ten, O. A. (2012). Vydelenie aktivnyh kul'tur fosfatmobilizirujushhih mikroorganizmov iz rizosfery. Biotehnologija [Isolation of active cultures of phosphate-mobilizing microorganisms from the rhizosphere]. Teorija i praktika, 3, pp. 77-82 [In Russian].

9. Roj, A. A., Bulavenko, L. A., \& Kurdish, I. K. (2001). Novye shtammy pochvennyh bacill, mineralizujushhie organicheskie soedinenija fosfora [New strains of soil bacilli, mineralizing organic phosphorus compounds]. Mikrobiolohichnyi zhurnal, 4 (63), pp. 9-14 [In Russian].

10. Rubin, B. A. (Ed.) (1969). Fiziologija sel'skohozjajstvennyh rastenij (Fiziologija kukuruzy $i$ risa) [Farm Plant Physiology (Corn and Rice Physiology)] (Vol. 5). Izd-vo Moskovskogo un-ta
[In Russian].

11. Chirikov, F. V. (1956). Agrohimija kalija $i$ fosfora [Agrochemistry of potassium and phosphorus]. Moskva: Gos. izd. s.-h. literatury [In Russian].

12. Yastrub, T. O., Kirsenko, V. V., Vakal, S. V., \& Korshun, M. M. (2013). Problema vazhkykh metaliv pry vyrobnytstvi i vykorystanni fosforovmisnykh mineralnykh dobryv (na prykladi Kadmiiu, Svyntsiu, Arsenu) [The problem of heavy metals in the production and use of phosphoruscontaining mineral fertilizers (for example, Cadmium, Lead, Arsen)]. Ukrainskyi zhurnal z problem medytsyny pratsi, 3 (36), pp. 42-49 [In Ukrainian].

13. Abel, S., Ticconi, C. A., \& Delatorre, C. A. (2002). Phosphate sensing in higher plants. Physiol. Plant, 115, pp. 1-8 [In English].

14. Bala, Rathinasabapathi, Xue, Liu, Yue, Cao, \& Lena, Q. Ma. (2018). Phosphate-solubilizing Pseudomonads for improving crop plant nutrition and agricultural productivity. Crop Improvement Through Microbial Biotechnology, pp. 363-372 [In English].

15. Braunova, O. \& Bernat, Y. (1980). Utilization of phosphorus from $\mathrm{Ca}_{3}\left(\mathrm{PO}_{4}\right)_{2}$ by soil micromycetes. Acta fac. rerum natur. Univ. comen. Microbiol, 8-9, pp. 129-142 [In English].

16. Kloepper, J. W., Ryn, C. M., \& Zhang, S. A. (2004). Systemic resistance and promotion of plant growth of Bacillus sp. Phytopathology, 94, pp. 1259-1266 [In English].

17. Md. Mahmudul, Hasan, Md. Mainul, Hasan, Jaime, A., Teixeira da, Silva, \& Xuexian, Li. (2016). Regulation of phosphorus uptake and utilization: transitioning from current knowledge to practical strategies. Cellular and Molecular Biology Letters, 21, pp. 1-9 [In English].

18. Park, J., Bolan, N., Mallavarapu, M., \& Naidu, R. (2010). Enhancing the solubility of insoluble phosphorus compounds by phosphate solubilizing bacteria. Brisbane, Australia. 19-th World Congres of Soil Science, pp. 65-68 [In English].

Токмакова Л. Н., Трепач А. А., Шевченко Л. А. Эффективность фосфорного питания растений кукурузы в результате воздействия Полимиксобактерином

Цель статьи - исследовать влияние различных способов применения микробного препарата Полимиксобактерина на фосфорное питание растений кукурузы и обосновать эффективность действия нового агроприёма.

Методика исследований. В процессе исследования использованы полевой метод, биохимические (определение содержания фосфора в зерне и листо-стеблевой массе растений), агрохимические (определение выноса фосфора с зерном и побочной продукиией) и статистические методы.

Результаты исследования. По результатам проведенных исследований установлено, что в среднем за три года исследований была выявлена тендениия увеличения содержания фосфора в зерне кукурузы вариантов с применением микробного препарата до 0,50-0,55\% по сравнению с контроль- 
ным вариантом, где этот показатель составил 0,47\%. Проведение обработки вегетирующих растений в фазе 7-9 листьев на фоне бактеризаџии увеличило общий вынос фосфора с урожсаем зерна на 53,2\%, с побочной продукцией на $36,3 \%$.

Элементы научной новизны. Выявлены особенности влияния нового способа применения Полимиксобактерина, который включает бактеризачию семян и поверхностную обработку вегетирующих растений, на интенсивность фосфорного питания кукурузы и вынос данного элемента с урожаем культуры.

Практическая значимость. На основе экспериментальных исследований установлено, что при выращивании кукурузы иелесообразно использовать агроприём, включающий бактеризацию семян и поверхностную обработку растений по вегетации Полимиксобактерином, который влияет на усиление усвоения фосфора растениями и способствует увеличению его содержания в листо-стеблевой массе и зерне кукурузы и, как следствие, повышается вынос данного элемента с урожаем культуры, что свидетельствует о повышении эффективности фосфорного питания растений кукурузы.

Ключевые слова: Zеa тауs L., микробный препарат Полимиксобактерин, фосфор, бактеризация семян, поверхностная обработка растений по вегетаиии.

Токмакова Любовь Николаевна - старший научный сотрудник, кандидат сельскохозяйственных наук, заведующий лабораторией экологии почвенных микроорганизмов, Институт сельскохозяйственной микробиологии и агропромышленного производства Национальной академии аграрных наук Украины, ул. Шевченко, 97, г. Чернигов, 14027, Украина, e-mail: tokmakova_ln@ukr.net, ORCID ID: 0000-0001-5501-2058.

Трепач Алла Алексеевна - кандидат сельскохозяйственных наук, старший научный сотрудник лаборатории экологии почвенных микроорганизмов, Институт сельскохозяйственной микробиологии и агропромышленного производства Национальной академии аграрных наук Украины, ул. Шевченко, 97, г. Чернигов, 14027, Украина, e-mail: alla.trepach@ukr.net, ORCID ID: 0000-0003-1059-9021.

Шевченко Любовь Анатольевна - младший научный сотрудник лаборатории экологии почвенных микроорганизмов, Институт сельскохозяйственной микробиологии и агропромышленного производства Национальной академии аграрных наук Украины, ул. Шевченко, 97, г. Чернигов, 14027, Украина, e-mail: shevchenkolyubov@ukr.net, ORCID ID: 0000-0002-2637-1999.

Tokmakova L. M., Trepach A. O., Shevchenko L. A. The effectiveness of phosphorus corn plants' nutrition with Polymixobacterin

The purpose of the article is to investigate the influence of various methods of using the Polymixobacterin microbial preparation on the phosphorous nutrition of corn plants and to substantiate the effectiveness of the new agricultural practice.

Methods of research. Field method, biochemical (determining phosphorus content in grain and leaf-stem part of plants) and agrochemical (determining grain and by-products' phosphorus yield) and statistical methods were used during the study.

The research results. According to the results of the conducted researches, it was established that on the average over the three years of investigations the tendency of increasing phosphorus content in corn grain of experimental variants with the application of a microbial preparation up to $0.50-0.55 \%$ was revealed in comparison with the control variant, in which this index was $0.47 \%$. Conducting the surface treatment of vegetating plants in the 7-9 leaf phase on the background of bacterization increased the total phosphorus removal in grain harvest by $53.2 \%$, and in by-product - by $36.3 \%$.

The elements of scientific novelty. The peculiarities of the impact of the new method of applying Polymixobacterin, which includes the bacterization of seeds and surface treatment of vegetating plants, on the intensity of phosphorus nutrition of corn and removing this element with the yield were revealed.

Practical significance. Based on the experimental studies it was established that at cultivating corn, it is expedient to use agricultural practices, which include seed bacterization and surface treatment of vegetating plants with Polymixobacterin, which affects the enhanced phosphorus assimilation by plants and contributes to increasing its content in leaf-stalk mass and corn grains, and as a consequence, the removal of this element in the crop yield is raised, which testifies to growing the effectiveness of phosphorous nutrition of corn plants.

Key words: Zea mays L., microbial preparation Polymixobacterin, phosphorus, bacterization of seeds, surface treatment of vegetating plants. 
Tokmakova Liubov Mykolaivna - Senior Researcher, Candidate (Ph.D.) of Agricultural Sciences, Head of the Laboratory of the Ecology of Soil Microorganisms, Institute of Agricultural Microbiology and AgroIndustrial Production of the National Academy of Agrarian Sciences of Ukraine, 97, Shevchenka st., Chernihiv, 14027, Ukraine, e-mail: tokmakova_ln@ukr.net, ORCID ID: 0000-0001-5501-2058.

Trepach Alla Oleksiivna - Candidate (Ph.D.) of Agricultural Sciences, Senior Researcher, Laboratory of the Ecology of Soil Microorganisms, Institute of Agricultural Microbiology and Agro-Industrial Production of the National Academy of Agrarian Sciences of Ukraine, 97, Shevchenka st., Chernihiv, 14027, Ukraine, e-mail: alla.trepach@ukr.net, ORCID ID: 0000-0003-1059-9021.

Shevchenko Liubov Anatoliivna - Junior Researcher, Laboratory of the Ecology of Soil Microorganisms, Institute of Agricultural Microbiology and Agro-Industrial Production of the National Academy of Agrarian Sciences of Ukraine, 97, Shevchenka st., Chernihiv, 14027, Ukraine, e-mail: shevchenkolyubov@ukr.net, ORCID ID:0000-0002-2637-1999.

Стаття надійшла до редакції 05.03.2019 р.

Бібліографічний опис для цитування :

Токмакова Л. М., Трепач А. О., Шевченко Л. А. Ефективність фосфорного живлення рослин кукурудзи за дії поліміксобактерину. Вісник ПДАА. 2019. № 1. С. 73-80.

DOI 10.31210/visnyk2019.01.09

(C) Токмакова Любов Миколаӥвна, Трепач Алла Олексївна, Шевченко Любов Анатолї̈вна, 2019 